Relations industrielles

Industrial Relations

\title{
The Family Division of Labour by Marie-Agnès \\ BARRÈRE-MAURISSON, Amsterdam : SISWO, 2000, 213 pp., ISBN \\ 90-6706-155-7.
}

\section{Diane-Gabrielle Tremblay}

Volume 57, numéro 3, été 2002

URI : https://id.erudit.org/iderudit/006892ar

DOI : https://doi.org/10.7202/006892ar

Aller au sommaire du numéro

Éditeur(s)

Département des relations industrielles de l’Université Laval

ISSN

0034-379X (imprimé)

1703-8138 (numérique)

Découvrir la revue

Citer ce compte rendu

Tremblay, D.-G. (2002). Compte rendu de [The Family Division of Labour by Marie-Agnès BARRÈRE-MAURISSON, Amsterdam : SISWO, 2000, 213 pp., ISBN 90-6706-155-7.] Relations industrielles / Industrial Relations, 57(3), 577-579. https://doi.org/10.7202/006892ar

Tous droits réservés (c) Département des relations industrielles de l’Université Laval, 2002
Ce document est protégé par la loi sur le droit d'auteur. L’utilisation des services d'Érudit (y compris la reproduction) est assujettie à sa politique d'utilisation que vous pouvez consulter en ligne.

https://apropos.erudit.org/fr/usagers/politique-dutilisation/ 
machinations of health care providers, insurance companies, and other parties interested in maintaining the status quo. He concludes that in spite of the clear advantages conferred by a national health insurance program, it is unlikely the United States will pursue that objective in the near future. Edith Rasell continues health care system critiques, returning to the attack on overly pessimistic funding assumptions. Rasell argues against the popular option of a health care voucher system. Among the concerns raised are difficulties with imperfect health service markets, assessing the appropriate voucher benefits for individuals with very different risk levels, and insurers "cherry-picking" only healthy applicants. Rasell suggests that rather than wholesale health care transformation, a series of small cost-cutting measures, minor tax increases and universal availability of Medicare would prove both more efficient and effective.

In chapter ten, Helene Jorgensen and Robert McGarragh shift the focus from benefit funding crises to coverage crises for contingent workers. Employers receive flexibility and cost advantages by limiting the number of permanent, full-time employees on staff, resulting in a dramatic increase in contingent workers and a corresponding decrease in the number of employees covered by health insurance and pensions. Nancy
Sedmark focuses on the issue of samesex partners. In many American states, homosexuality and co-habitation (samesex or heterosexual) remain a criminal offence. This creates difficulties for more progressive organizations that would choose to extend benefit coverage to the partners of employees in this group. Sedmak looks at the legal and moral issues and then offers practical guidance for those wishing to add samesex partner benefits to their current programs.

The contributors to this IRRA volume have raised important concerns regarding benefit coverage and the validity of the received view on social security funding. It is difficult, however to feel entirely content with the collection. Although there are understandable space limitations within such a publication, it remains disappointing that none of the authors offers anything more than very generalized recommendations for change. The investigations are irreproachable but leave the reader unsatisfied. This criticism is minor, however, as the volume is particularly timely and provides sound scholarship, instructive in the evaluation of worldwide social security debates.

Kelly Williams University of Calgary

\section{The Family Division of Labour}

by Marie-Agnès BARRÈRE-MAurisSOn, Amsterdam : SISWO, 2000, 213 pp., ISBN 90-6706-155-7.

Barrère-Maurisson is already wellknown in French-speaking countries in the field of family division of labour and on issues related to work-family balancing, among others. This book is a translation of a work first published in French in 1992, but it has been re-edited to include the author's most recent research. A preface to the English edition is also of interest and may help researchers and students to understand the essence of the author's theoretical proposals.

The author examines the relationship between work and family and the two spheres are considered simultaneously, which is an original perspective, although more frequent since work-family balancing issues came to the forefront in the 
90s. Still, to date, few researchers in Industrial Relations have worked on both dimensions at the same time.

The author also defends the differences between societies and the concept of a specific regulation for each of these societies. She indicates that there are high levels of overall coherence within individual societies and that within each society, or within each time period in a given society, there is a specific mode of regulation which is an expression of a specific relationship between the dominant economic structure and particular family structures. In this analysis, the author draws on some elements of the French Regulationist School but extends her consideration to include family issues, which results in a very interesting theoretical perspective The author notes that this particular mode of societal regulation (familial, market or political) varies from country to country and from one period to another. There are complex interactions between social institutions and the diverse roles played by the family, firms, the market and the State in each society and at different time periods. This interesting theoretical construct is developed in this book and it is surely of interest to researchers and students of industrial relations, sociology of work and labour economics.

The first chapter underlines the need for a new approach to family and work issues, stating these should be considered simultaneously. Then the author stresses the need for a linkage between the spheres of work and family, rather than the usual separation observed in many books or research studies. She exposes economic and sociological views on family and work issues and then presents her own perspective supporting the three assumptions underlying her theoretical construct, i.e. the linkage principle, the genetic principle and the regulation principle.

The second chapter presents a view of the historical evolution existing between work and the family in the $20^{\text {th }}$ Century in France. This analysis can be extended to other countries, even if specific years and periods will vary from country to country. The distribution of paid and domestic work and family types is analysed in this chapter. Chapter 3 deals with agriculture and selfemployment situations and looks at the evolution of non-wage work and changes in the family context.

Part II of the book opens with Chapter 4, which more fully develops the concepts of work and family that are pertinent to the author's theoretical construction. The book's essence is here since this chapter discusses the theoretical construction in detail. Chapter 5 examines methods which can be used to validate the theory and could be useful for students who wish to use the approach presented here in their own work.

Chapter 6 opens part III, and develops the various principles that the author wishes to highlight. Chapter 6 explains the periodisation principle and draws attention to changes over time in the work-family relationship. Chapter 7 points out local specificity as well as social categories. Finally, chapter 8 explores the international perspective and presents, among other elements, a comparison between France and Great Britain. The author puts an emphasis on societal forms of the relationship and also compared macro-social modes of regulation. These comparisons enable English-language readers who have not yet become acquainted with the Institutionalist or Regulationist French School of economists (Robert Boyer, Alain Lipietz, Michel Aglietta, etc.) to become familiar with these extremely interesting theories, as well as with the French School of Societal analysis, from the Laboratoire d'économie et de sociologie du travail (LEST) in Aix-en-Provence (Marc Maurice, Jean-Jacques Silvestre, amongst other authors from LEST). Although these two schools had some works published in English, they are not 
necessarily as well known as they should be in the USA and English-speaking (reading) countries.

The book is clearly to be recommended to all researchers and students interested in issues pertaining to the family or to work, or to both at the same time. A bibliography at the end of each chapter offers references making possible a more in-depth exploration of some issues, either the Regulationist School, family issues or work and employment issues. I do not think any other English publication presents this particular perspective, and this fact certainly justifies the translation and updating of this book.

\section{Diane-Gabrielle Tremblay} Université du Québec

\section{Polarizing Mexico: The Impact of Liberalization Strategy}

by Enrique Dussel Peters, Boulder, Colorado: Lynne Rienner Publishers, 2000, 249 pp., ISBN 1-55587-861-X (bound).

\section{Growth, Employment and Equity: The Impact of the Economic Reforms in Latin America and the Caribbean}

by Barbara Stallings and Wilson Peres, Washington, D.C.: Brookings Institution Press and United Nations Economic Commission for Latin America and the Caribbean, 2000, 252 pp., ISBN 0-8157-8087-7 (paper).

Since 1982 the economies of the poorer countries of the Americas have been profoundly restructured along the lines prescribed by the "Washington Consensus." The standard list of prescribed policies includes: (a) radically reducing tariff and non-tariff barriers to trade; (b) eliminating foreign exchange and capital controls; (c) deregulating major industries, including finance; (d) selling most public corporations; (e) reducing union collective bargaining power and promoting labour market "flexibility"; (f) reducing central bank political accountability and narrowly focusing monetary policy on minimizing inflation; $(\mathrm{g})$ cutting social expenditures to balance government budgets without regard to the business cycle; and (h) eliminating most government subsidies, including those targeted on the poor (e.g., food subsidies for the urban poor, cheap credit for small farmers). The new policies were generally introduced as "structural adjustment" conditions attached to World Bank, IMF, and government loans to refinance foreign debts.

Proponents of this "neoliberal" (i.e., market liberalization) reform package argued it would have four sets of desirable effects. First, it would improve macroeconomic stability (i.e., end hyper-inflation, chronic trade deficits, and massive currency devaluations). Second, it would increase exports, hence foreign currency earnings, hence capacity to meet foreign debt payments. Third, it would increase foreign investment levels and allocate investment more efficiently, increasing labour productivity and economic growth rates, thereby boosting formal sector job creation and real wages. Finally, it would reduce income inequality as farmers were paid more for their products, and unskilled workers were paid more relative to skilled workers.

The books under review ask which of the promises made by neoliberal reformers have been realized, and where they have not been, what went wrong. Enrique Dussel Peters, an economist at the National Autonomous University (UNAM) in Mexico City, offers the most detailed and penetrating analysis of the effects of the liberalization of Mexico's economy that this reviewer has encountered in English. Stallings and Peres are researchers at the United Nations' 